\title{
Effect of cytokine-induced killer cells on immune function in patients with lung cancer
}

\author{
YANYAN PAN $^{1}$, YUANYUAN WU ${ }^{1}$, JUN JI ${ }^{1}$, HONGJIAO CAI ${ }^{1}$, HESHUANG WANG ${ }^{1}$, YIFAN JIANG ${ }^{1}$, \\ LIMIN SANG $^{1}$, JIN YANG ${ }^{1}$, YANYAN GAO ${ }^{1}$, YING LIU ${ }^{1}$, LIANGWEI YIN $^{2}$ and LI ZHANG ${ }^{1}$ \\ Departments of ${ }^{1}$ Central Laboratory and ${ }^{2}$ Cell Biological Treatment, \\ Dalian Municipal Central Hospital, Dalian, Liaoning 116033, P.R. China
}

Received February 3, 2015; Accepted January 27, 2016

DOI: $10.3892 / \mathrm{ol} .2016 .4284$

\begin{abstract}
Cytokine-induced killer (CIK) cells have been used as adoptive immunotherapy in cancer. The present study evaluated the effect of CIK cells on immune function in patients with lung cancer. Patients were divided into three groups, according to the treatment received prior to CIK cell treatment: CIK group (no prior treatment), Che-Sur group (prior chemotherapy and surgery) and Che-Rad group (prior chemotherapy and radiotherapy). Following treatment, the average percentage of cluster of differentiation (CD) $3^{+} \mathrm{CD} 4^{+}$, $\mathrm{CD}^{+}$, natural killer (NK) and NKT cells in peripheral blood was significantly higher than that prior to CIK treatment in the Che-Sur and CIK groups, and the levels of interferon- $\gamma$ in serum were significantly higher than those prior to CIK treatment in the Che-Sur and CIK groups. On the contrary, the levels of interleukin-10 had decreased in these groups following CIK treatment. Subsequently, patients were divided into three groups according to the percentage of $\mathrm{CD}^{+} \mathrm{CD}^{+} 6^{+}$ CIK cells that were administered to the patients. The number of NK and NKT cells increased with increasing number of $\mathrm{CD}^{+}{ }^{+} \mathrm{CD} 56^{+}$cells. The patients in the CIK and Che-Sur groups were the most benefited ones following CIK treatment, contrarily to those in the Che-Rad group, since the increase in the number of $\mathrm{CD}^{+} \mathrm{CD} 56^{+} \mathrm{CIK}$ cells in the aforementioned patients enhanced the number of NK cells, which exhibit antitumor activity.
\end{abstract}

\section{Introduction}

Lung cancer is one of the most common form of cancer and has a poor prognosis (1). Surgical treatment is the best option currently available to manage advanced refractory lung tumors (2). Chemotherapy may be useful, but cannot be

Correspondence to: Mr. Li Zhang, Department of Central Laboratory, Dalian Municipal Central Hospital, 826 Xinan Road, Shahekou, Dalian, Liaoning 116033, P.R. China

E-mail: tyouri19652004@hotmail.com

Key words: cytokine-induced killer cells, immune function, lung cancer administered to the majority of patients with lung cancer in advanced stages due to poor tolerance (3). Recent advances in the novel approach of adoptive immunotherapy for the treatment of advance lung cancer are promising for the management of these patients (4).

Cytokine-induced killer (CIK) cells are a heterogeneous population of ex vivo expanded T lymphocytes with diverse $\mathrm{T}$ cell receptor specificities, and are endowed with non-major histocompatibility complex (MHC)-restricted cytotoxic activities against tumor cells (5). This antitumor activity is mainly associated with cluster of differentiation (CD) $3{ }^{+} \mathrm{CD} 56^{+}$ cells (6).

The antitumor effects of CIK cells against a number of hematologic and solid malignancies have been described in murine tumor models and clinical studies (6-8). In the severe combined immunodeficiency (SCID) mouse model, infusion of human CIK cells significantly prolonged survival of SCID mice, compared with control animals or those infused with lymphokine activated killer cells (9). In other studies using the SCID model, CIK cells exhibited in vivo antitumor activity against a number of hematopoietic and solid tumors (10). The first clinical study on CIK cells included 10 patients with metastatic renal carcinoma, colorectal cancer and lymphoma (8). Of these, 1 patient with lymphoma experienced complete remission, while 6 patients exhibited disease progression, and 3 did not experience any alteration on their condition $(5,11)$. Other clinical studies subsequently confirmed the safety and benefits of CIK cell-based therapy, alongside initial clinical activity $(12,13)$.

Adaptive and innate cellular immunity are important factors that act against tumor growth and aid the clearance of cancer (14). Adoptive immunotherapy relies on the ability of the body to efficiently kill tumor cells and promote immune responses (9). The number of immune cells, particularly type $1 \mathrm{~T}$ helper (Th1) cells, $\mathrm{CD}^{+} \mathrm{T}$ cells, natural killer (NK) and NKT cells is associated with the survival of cancer patients (14). Such antitumor cellular immune responses may be greatly enhanced by adoptive transfer of CIK cells $(14,15)$.

Several studies have reported that a combination of chemotherapy, surgical operation and radiotherapy alongside CIK cell therapy may control local tumors while promoting antitumor activity and immune responses $(12,16)$. However, as a newly emerging treatment method, we hypothesize that 
there are several challenges that remain to be addressed to maximize the benefits of the treatment, including the course of CIK cell immunotherapy, the percentage of $\mathrm{CD}^{+} \mathrm{CD}^{+} 6^{+}$ cells among the CIK cells administered to the patient and the effect of previous treatments on immune function in cancer patients. Since CIK cell treatment has a pivotal role in patients with lung cancer, the interpretation of the aforementioned concerns is important when considering different treatment options for these patients. In the present study, flow cytometry data of peripheral blood from patients with lung cancer was collected to retrospectively analyze whether the course of CIK cell immunotherapy, previous treatments and percentage of $\mathrm{CD}^{+}{ }^{+} \mathrm{CD} 56^{+} \mathrm{CIK}$ cells have affected the immune function in these patients.

\section{Materials and methods}

Patients. Patients with lung cancer who attended Dalian Municipal Central Hospital (Dalian, China) from November 2011 to May 2014 and agreed to receive CIK treatment were included in the present study. Following histological or imaging examination, all patients were diagnosed with stage II-IV lung cancer, according to the tumor-node-metastasis (TNM) staging system, published by the International Union Against Cancer in 2009 (17). Exclusion criteria were as follows: i) History of autoimmune disease or chronic wasting disease and infectious diseases; ii) use of immunosuppressive agents or notable psychiatric disease; iii) evidence of other malignancies; and iv) reception of CIK treatment prior to the study. The present study was approved by the Ethics Committee of Dalian Municipal Central Hospital. All patients provided written informed consent prior to treatment initiation.

Patients were divided into three groups according to the treatment received prior to enrollment in the study: i) CIK group, which included patients who had not received any treatment prior to CIK treatment; ii) Che-Sur group, which included patients who had received 1-2 courses of chemotherapy and surgical procedures prior to CIK treatment; and iii) Che-Rad group, which included patients who had received 1-2 courses of chemotherapy and 1-2 courses of radiotherapy prior to CIK treatment.

All patients were administered CIK treatment and standardized chemotherapy upon enrolment, based on the patients' decision to undergo the treatment. Patients were divided into three groups, according to the percentage of $\mathrm{CD}^{+} \mathrm{CD}^{+} 6^{+}$cells received during each course of CIK treatment. The percentage of $\mathrm{CD}^{+} \mathrm{CD}^{+} 6^{+}$cells received by each group was as follows: $<10 \%$ for group 1 (Low-CIK group); $10-20 \%$ for group 2 (Mid-CIK group); and $>20 \%$ for group 3, (High-CIK group). Among these groups, no significant differences were observed in regards to patients' age, gender, tumor size, tumor stage, histopathological type and TNM stage.

Preparation of CIK cells. In vitro expansion and reinfusion of autologous immune cells of the patients was conducted as follows: Peripheral blood mononuclear cells (PBMCs) were isolated from $50 \mathrm{ml}$ samples of peripheral blood from patients by Ficoll density gradient centrifugation at 1,258 x g for $10 \mathrm{~min}$ (GT5-4; Beijing Era Beili Centrifuge Co., Ltd., Beijing, China), as previously described (18). The yield of PBMCs isolated was $\sim 3-4 \times 10^{7}$ cells. Next, PBMCs were cultured in X-VIVO ${ }^{\text {TM }}$ complete medium (Lonza Group Ltd., Basel, Switzerland) supplemented with $1 \%$ interferon (IFN)- $\gamma$ (eBioscience, Inc., San Diego, CA, USA) and 1\% interleukin (IL)-2 (3SBio Inc., Shenyang, China). Cells were seeded in culture flasks, and purified mouse anti-human monoclonal CD3 (clone, OKT3; cat. no. 16-0037-85; dilution, 1:100; eBioscience, Inc.) and mouse anti-human monoclonal CD28 (clone, CD28.2; cat. no. 14-028982; dilution, 1:100; eBioscience, Inc.) antibodies were added. The cells were incubated at $37^{\circ} \mathrm{C}$ with $5 \% \mathrm{CO}_{2}$. Culture medium was added every 2-3 days. Cells were harvested 2 weeks later. At the end of the culture, a bacterial culture test was performed. Cells free of contamination by microorganisms were collected, and $\sim 7-9 \times 10^{9}$ cells were harvested in $100 \mathrm{ml}$ normal saline (Huaren Pharmaceutical Co., Ltd., Qingdao, China) with $1 \mathrm{ml}$ human serum albumin (Grifols USA, Los Angeles, CA, USA), and administered to the patients once daily for 3 consecutive days via the superficial vein.

Chemotherapy. Following the collection of peripheral blood from patients, chemotherapy was started on that day or 1 day later. Following culture for 14 days, CIK cells were transfused back into the patients. These transfusions were defined as one course. The subsequent course was performed 30 days following the last collection of peripheral blood. The number of courses performed was decided by the patients.

Patients with non-small cell lung cancer were treated with intravenous gemcitabine $\left(1,000 \mathrm{mg} / \mathrm{m}^{2}\right.$, days 1 and 8 in 30 day cycle; Jiangsu Hansoh Pharmaceutical Co., Ltd., Lianyungang, China) plus intravenous platinum $\left(35-45 \mathrm{mg} / \mathrm{m}^{2}\right.$, days $1-2$ in 30 day cycle; Jiangsu Hansoh Pharmaceutical Co., Ltd.), whereas patients with small cell lung cancer were treated with intravenous etoposide $\left(100 \mathrm{mg} / \mathrm{m}^{2}\right.$, days $1-3$ in 30 days cycle; Jiangsu Hengrui Medicine Co., Ltd., Lianyungang, China) plus intravenous cisplatin $\left(40 \mathrm{mg} / \mathrm{m}^{2}\right.$, days $1-3$ in 30 day cycle; Jiangsu Hansoh Pharmaceutical Co., Ltd.). If any of the patients presented a contraindication to that protocol, an alternative protocol was then selected.

Flow cytometry. A total of $2 \mathrm{ml}$ blood was extracted from each patient to detect the subsets of $\mathrm{CD}^{+} \mathrm{CD}^{+} \mathrm{T}, \mathrm{CD}^{+} \mathrm{T}, \mathrm{NK}$ and NKT cells 1 day prior to each CIK course. Unless otherwise indicated, all antibodies were purchased from Beckman Coulter, Inc. (Brea, CA, USA).

The following antibodies were used to analyze the cells: Fluorescein isothiocyanate (FITC)-conjugated mouse anti-human monoclonal CD4 (clone, 13B8.2; cat. no. IM1650; dilution, ready to use), phycoerythrin-cyanine 5-conjugated mouse anti-CD3 (clone, UCHT1; cat. no. IM1650; dilution, ready to use), phycoerythrin-conjugated mouse anti-CD16/56 (clone, 3G8; cat. no. A07735; dilution, ready to use) and mouse FITC-conjugated anti-CD3 (clone, UCHT1; cat. no. A07746; dilution, ready to use) (all purchased from Beckman Coulter, Inc.). The above monoclonal antibodies $(20 \mu \mathrm{l})$ were added to $100 \mu \mathrm{l}$ fresh ethylenediaminetetraacetic acid (BD Biosciences, Franklin Lakes, NJ, USA)-anticoagulated peripheral blood, mixed and stained in the darkness at room temperature for $20 \mathrm{~min}$. Next, $1.0 \mathrm{ml}$ erythrocyte lysis buffer (Beckman Coulter, Inc.) was added, mixed and incubated in the darkness at room temperature for $10 \mathrm{~min}$ to lyse the erythrocytes. The 
Table I. Clinical characteristics of patients with lung cancer included in the present study prior to CIK treatment ( $\mathrm{n}=57$ ).

\begin{tabular}{|c|c|c|c|c|}
\hline Characteristic & Total $(\mathrm{n}=57)$ & CIK $(n=17)$ & Che-Sur $(n=21)$ & Che-Rad $(n=19)$ \\
\hline \multicolumn{5}{|l|}{ Patient } \\
\hline Gender (M/F) & $40 / 17$ & $13 / 4$ & $13 / 8$ & $14 / 5$ \\
\hline Age, years & $63.5 \pm 11.3$ & $64.6 \pm 12.9$ & $63.8 \pm 12.2$ & $62.1 \pm 8.0$ \\
\hline \multicolumn{5}{|l|}{ Tumor stage } \\
\hline II & 7 & 3 & 3 & 1 \\
\hline III & 7 & 2 & 1 & 4 \\
\hline IV & 43 & 12 & 17 & 14 \\
\hline \multicolumn{5}{|l|}{ Histopathological type } \\
\hline Adenocarcinoma & 17 & 6 & 4 & 5 \\
\hline Squamous cell carcinoma & 10 & 1 & 8 & 3 \\
\hline Small cell lung cancer & 11 & 2 & 3 & 7 \\
\hline Adenosquamous carcinoma & 5 & 1 & 3 & 1 \\
\hline Not determined & 14 & 7 & 3 & 3 \\
\hline
\end{tabular}

CIK, cytokine-induced killer; Che, chemotherapy; Sur, surgery; Rad, radiotherapy; M, male; F, female.

mixture was then centrifuged at 2,000 x g for 5 min [L-500; ZiHe International Trade (Shanghai) Co., Ltd., Shanghai, China], and the supernatant was discarded. Subsequently, $1 \mathrm{ml} 1 \mathrm{X}$ phosphate-buffered saline (Shijiazhuang Tianshun Biotechnology Co., Ltd., Shijiazhuang, China) was added into each tube, mixed and centrifuged at 2,000 x g for $5 \mathrm{~min}$ [L-500; ZiHe International Trade (Shanghai) Co., Ltd.] to remove the supernatant. From each tube, 10,000 cells were obtained, which were then tested using a FC 500 flow cytometer (CXP2.1; Beckman Coulter, Inc.).

Detection of cytokines by enzyme-linked immunosorbent assay (ELISA). Levels of IFN- $\gamma$ and IL-10 were measured using commercial ELISA kits (R\&D Systems, Inc., Minneapolis, MN, USA) according to the manufacturer's protocol. The optical density values at $450 \mathrm{~nm}$ were measured in a microplate reader (VICTOR3 V 1420 Multilabel Counter; PerkinElmer, Inc., Waltham, MA, USA). The concentration of cytokines in each sample was calculated using a standard curve generated by Microsoft Excel 2007 software (Microsoft Corporation, Redmond, WA, USA) using recombinant cytokines (R\&D Systems, Inc.).

Statistical analysis. Data are presented as the mean \pm standard error (SE). Statistical significance of the differences was analyzed by $t$-test for data of two groups, and one-way analysis of variance for data of three groups. Pairwise comparison was performed using Student-Newman-Keuls test, and differences in the distribution of selected clinical characteristics were evaluated by $\chi^{2}$ test, using SPSS version 17.0 software (SPSS, Inc., Chicago, IL, USA). $\mathrm{P}<0.05$ was considered to indicate a statistically significant difference.

\section{Results}

Patients' profile. From November 2011 to May 2014, a total of 57 patients aged $40-86$ years (mean, $63.5 \pm 11.3$ years) were

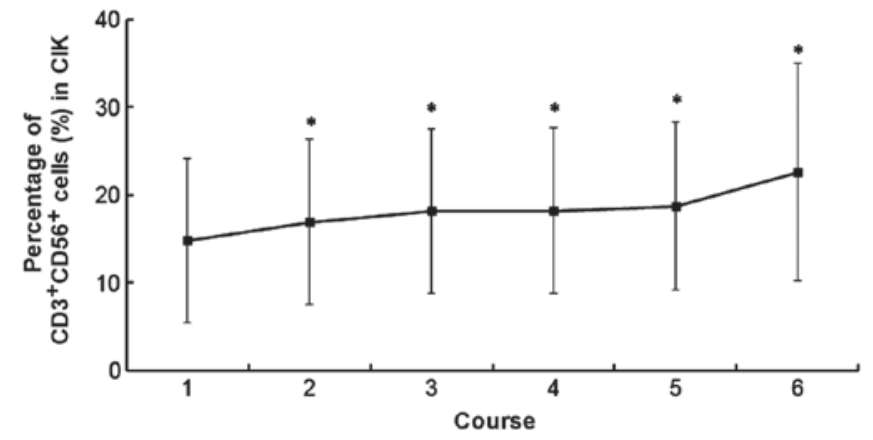

Figure 1. Percentage of $\mathrm{CD}^{+} \mathrm{CD}^{+} 6^{+} \mathrm{CIK}$ cells in vitro during each course of CIK treatment. ${ }^{*} \mathrm{P}<0.05$ vs. the first course. $\mathrm{CD}$, cluster of differentiation; CIK, cytokine-induced killer.

included in the present study. The baseline characteristics of the patients are shown in Table I. There were no significant differences in the clinical characteristics of the patients included in the CIK, Che-Sur and Che-Rad groups.

Administration of CIK cells. The proliferation of PBMCs following CIK induction varied between individuals. On average, the number of PBMCs increased $>100$-fold following 14 days of incubation. The number of CIK cells peaked at day 14 . A minimum of $7-9 \times 10^{9} \mathrm{CIK}$ cells were harvested and transfused into the patients every day since day 12 to day 14 , for a total of three times. The average total number of CIK cells was $8.2 \times 10^{9}$ cells for all patients. The average number of courses of CIK infusion was 2.8 (range, 1-11 courses). The number of $\mathrm{CD}^{+} \mathrm{CD}^{+} 6^{+} \mathrm{CIK}$ cells in courses $1,2,3,4$, 5 and 6 was $14.8 \pm 9.3,16.9 \pm 9.5,18.2 \pm 9.3,18.2 \pm 9.4,18.7 \pm 9.6$ and $22.6 \pm 12.4$ cells, respectively (Fig. 1).

Immune status in patients with lung cancer following CIK treatment. The number of immune cells present in the peripheral blood of the patients was analyzed following each course of 
Table II. Number of immune cells in the peripheral blood of patients following each course of CIK treatment.

\begin{tabular}{|c|c|c|c|c|c|}
\hline \multirow[b]{2}{*}{ Cells } & \multirow[b]{2}{*}{ Prior to CIK treatment } & \multicolumn{4}{|c|}{ Following CIK treatment (course, $\mathrm{n}$ ) } \\
\hline & & 1 & 2 & 3 & 4 \\
\hline \multicolumn{6}{|l|}{$\mathrm{CD}^{+} \mathrm{CD}^{+}(\%)$} \\
\hline CIK group & $34.4 \pm 9.3$ & $28.7 \pm 8.8$ & $31.7 \pm 10.7$ & $36.7 \pm 4.9$ & $41.3 \pm 9.3^{\mathrm{a}}$ \\
\hline Che-Sur group & $38.8 \pm 8.8$ & $41.7 \pm 10.5$ & $48.2 \pm 8.7^{\mathrm{a}}$ & $40.5 \pm 5.9$ & $44.5 \pm 2.9$ \\
\hline Che-Rad group & $26.4 \pm 7.6$ & $26.1 \pm 7.4$ & $26.0 \pm 9.4$ & $24.6 \pm 5.9$ & $24.5 \pm 5.0$ \\
\hline P-value & 0.002 & 0.005 & 0.008 & 0.038 & 0.002 \\
\hline \multicolumn{6}{|l|}{$\mathrm{CD}^{+}(\%)$} \\
\hline CIK group & $62.7 \pm 9.3$ & $55.4 \pm 9.0$ & $63.0 \pm 13.1$ & $77.4 \pm 7.3^{\mathrm{a}}$ & $79.8 \pm 6.6^{\mathrm{a}}$ \\
\hline Che-Sur group & $69.9 \pm 6.9$ & $70.8 \pm 8.6$ & $75.9 \pm 4.7^{\mathrm{a}}$ & $69.5 \pm 9.1$ & $78.5 \pm 1.8^{\mathrm{a}}$ \\
\hline Che-Rad group & $68.0 \pm 11.8$ & $65.4 \pm 12.6$ & $68.3 \pm 15.3$ & $64.6 \pm 12.2$ & $66.2 \pm 12.7$ \\
\hline P-value ${ }^{b}$ & 0.187 & 0.051 & 0.173 & 0.206 & 0.168 \\
\hline \multicolumn{6}{|c|}{$\mathrm{CD}^{-} \mathrm{CD}^{-} 6^{+} 56^{+}(\mathrm{NK})(\%)$} \\
\hline CIK group & $18.8 \pm 9.1$ & $18.0 \pm 7.0$ & $22.5 \pm 5.7$ & $24.1 \pm 4.9$ & $19.4 \pm 5.9$ \\
\hline Che-Sur group & $19.7 \pm 9.4$ & $19.4 \pm 9.2$ & $18.1 \pm 10.1$ & $18.3 \pm 12.5$ & $19.5 \pm 14.0$ \\
\hline Che-Rad group & $23.7 \pm 12.9$ & $27.1 \pm 9.8$ & $22.3 \pm 12.1$ & $26.4 \pm 12.3$ & $20.3 \pm 7.5$ \\
\hline P-value & 0.514 & 0.027 & 0.643 & 0.381 & 0.993 \\
\hline \multicolumn{6}{|c|}{$\mathrm{CD}^{+} \mathrm{CD} 16^{+} 56^{+}(\mathrm{NKT})(\%)$} \\
\hline CIK group & $11.5 \pm 5.4$ & $12.0 \pm 7.2$ & $10.6 \pm 5.6$ & $14.3 \pm 3.9$ & $12.4 \pm 6.4$ \\
\hline Che-Sur group & $4.9 \pm 2.4$ & $6.6 \pm 4.7$ & $5.6 \pm 3.2$ & $6.3 \pm 3.0$ & $8.4 \pm 4.0^{\mathrm{a}}$ \\
\hline Che-Rad group & $10.9 \pm 9.2$ & $10.9 \pm 11.9$ & $11.2 \pm 9.7$ & $10.3 \pm 12.0$ & $7.7 \pm 4.4$ \\
\hline P-value ${ }^{b}$ & 0.019 & 0.385 & 0.222 & 0.513 & 0.437 \\
\hline
\end{tabular}

${ }^{\mathrm{a}} \mathrm{P}<0.05$ vs. control in the same treatment group compared with different $\mathrm{CIK}$ treatment courses. ${ }^{\mathrm{b}} \mathrm{P}<0.05$ vs. control in same $\mathrm{CIK}$ treatment course compared with different treatment groups CIK, cytokine-induced killer; CD, cluster of differentiation; NK, natural killer.

Table III. Levels of INF- $\gamma$ and IL-10 in serum of patients with lung cancer prior and subsequent to CIK treatment.

\begin{tabular}{|c|c|c|c|c|c|c|}
\hline \multirow[b]{2}{*}{ Group } & \multicolumn{2}{|c|}{ CIK } & \multicolumn{2}{|c|}{ Che-Sur } & \multicolumn{2}{|c|}{ Che-Rad } \\
\hline & $\begin{array}{c}\text { Prior to } \\
\text { CIK treatment }\end{array}$ & $\begin{array}{l}\text { Following } \\
5 \text { courses }\end{array}$ & $\begin{array}{c}\text { Prior to } \\
\text { CIK treatment }\end{array}$ & $\begin{array}{c}\text { Following } \\
5 \text { courses }\end{array}$ & $\begin{array}{c}\text { Prior to } \\
\text { CIK treatment }\end{array}$ & $\begin{array}{c}\text { Following } \\
5 \text { courses }\end{array}$ \\
\hline IFN- $\gamma(\mathrm{pg} / \mathrm{ml})$ & $15.6 \pm 5.1$ & $27.7 \pm 5.5^{\mathrm{a}}$ & $12.5 \pm 2.6$ & $22.4 \pm 12.1^{\mathrm{a}}$ & $22.4 \pm 6.6$ & $27.9 \pm 6.5$ \\
\hline IL-10 (pg/ml) & $20.4 \pm 5.7$ & $16.2 \pm 1.3$ & $29.1 \pm 9.1$ & $16.0 \pm 3.2^{\mathrm{a}}$ & $49.8 \pm 13.5$ & $46.3 \pm 10.3$ \\
\hline
\end{tabular}

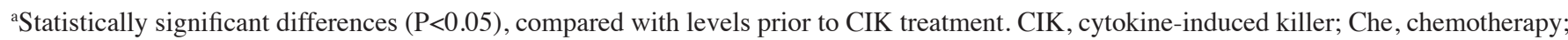
Sur, surgery; Rad, radiotherapy; IFN, interferon; IL, interleukin.

CIK treatment in the three groups (CIK-group, Che-Sur group and Che-Rad group). In the CIK-group, following 4-5 courses of treatment, the average percentage of $\mathrm{CD}^{+} \mathrm{CD}^{+}$and $\mathrm{CD}^{+}$cells were significantly higher $(\mathrm{P}=0.043$ and 0.033 , respectively) than those prior to CIK treatment (control). In the Che-Sur group, following 3-4 courses of CIK treatment, the average percentage of $\mathrm{CD}^{+} \mathrm{CD}^{+}, \mathrm{CD}^{+}$and $\mathrm{NKT}$ cells was significantly higher than that prior to CIK treatment $(\mathrm{P}=0.036,0.040$ and 0.047 , respectively). In the Che-Rad group, the average percentage of $\mathrm{CD}^{+} \mathrm{CD}^{+}, \mathrm{CD}^{+}, \mathrm{NK}$ and NKT cells was not altered following 5 courses of $\mathrm{CIK}$ treatment, compared with the values prior to the treatment $(\mathrm{P}=0.542,0.743,0.533$ and 0.360 , respectively).
In addition, the differences in cell number across the three treatment groups were also compared. The average percentage of $\mathrm{CD}^{+}{ }^{+} \mathrm{CD} 4^{+}$cells in the Che-Rad group was significantly lower than that in CIK and Che-Sur groups in each course $(\mathrm{P}=0.005,0.008,0.038$ and 0.002 , respectively), whereas the average percentage of $\mathrm{CD}^{+}$cells did not differ between the three groups $(\mathrm{P}=0.051,0.173,0.206$ and 0.168 , respectively). The average percentage of NK cells in the Che-Rad group was significantly higher than that observed in the CIK and Che-Sur groups following the first course of CIK treatment $(\mathrm{P}=0.027)$. The average percentage of NKT cells in CIK and Che-Rad groups was significantly higher than that 
A

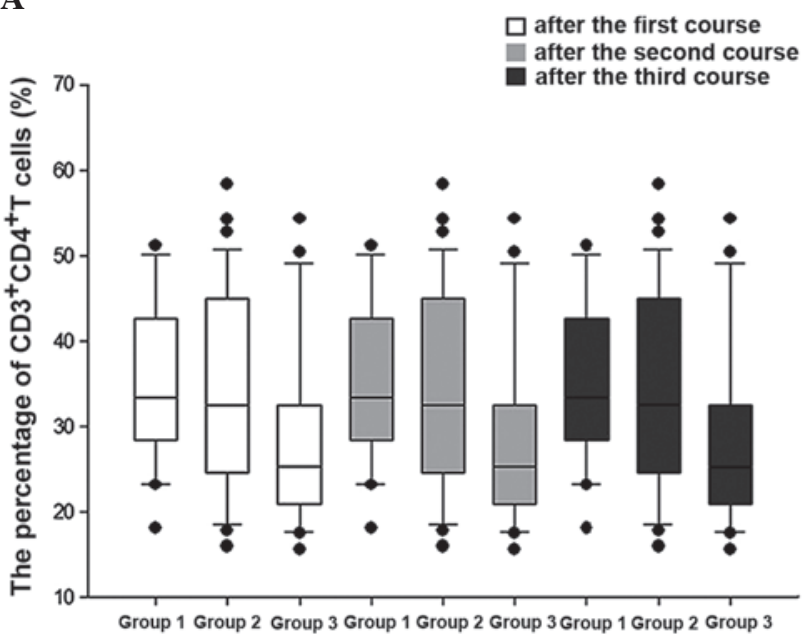

C

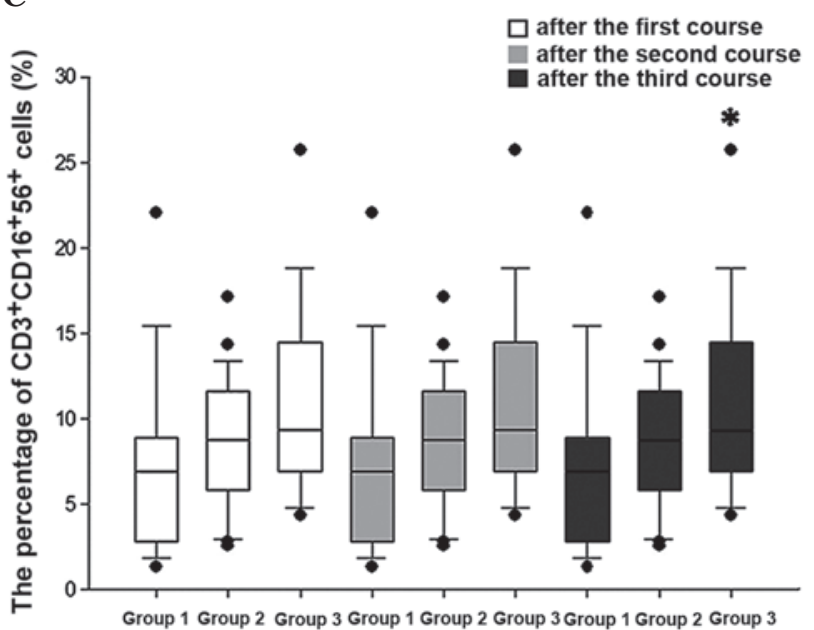

B

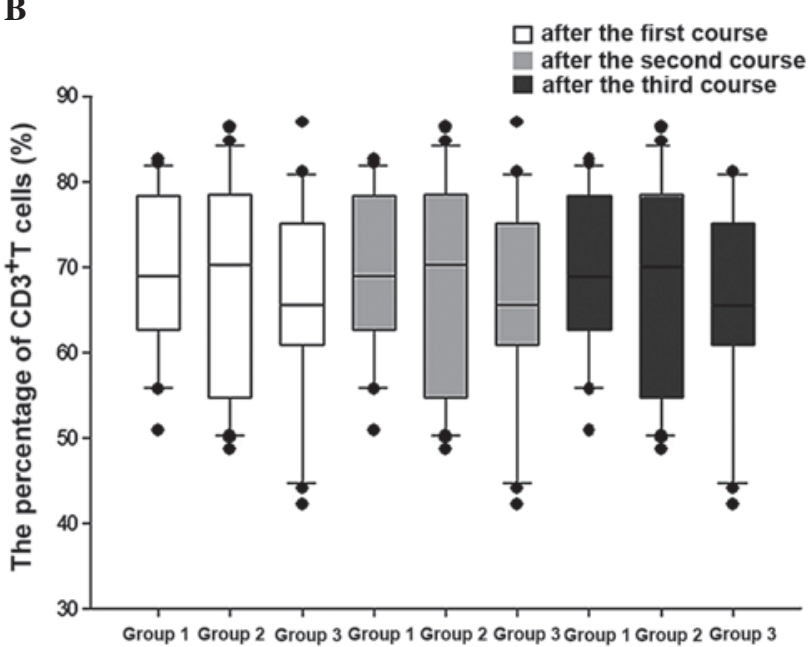

D

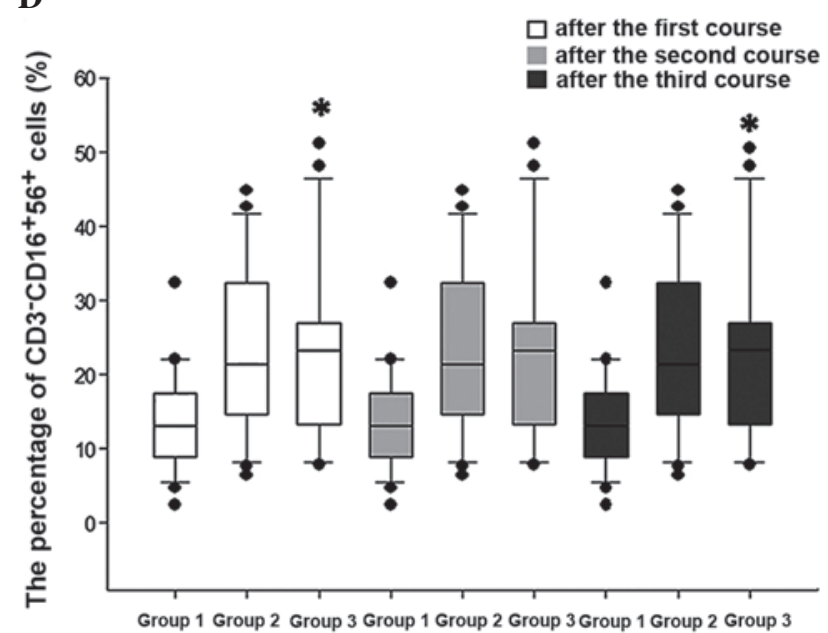

Figure 2. Effects of the percentage of $\mathrm{CD}^{+} \mathrm{CD}^{2} 6^{+} \mathrm{CIK}$ cells on the regulation of the immune function in patients with lung cancer. Differences in the levels of (A) $\mathrm{CD3}^{+} \mathrm{CD}^{+}$, (B) $\mathrm{CD}^{+}$, (C) NKT and (D) NK cells were compared between the three groups (Low-CIK, Mid-CIK and High-CIK). Cell levels in the peripheral blood of patients were measured the day prior to the following course of CIK treatment and subsequent to the first three courses. "P<0.05 vs. Low-CIK group. $\mathrm{CD}$, cluster of differentiation; CIK, cytokine-induced killer; NK, natural killer.

observed in the Che-Sur group prior to the first course of CIK treatment $(\mathrm{P}=0.019)$. Data are presented in Table II.

The serum levels of INF- $\gamma$ and IL-10 were also detected in the three groups of patients (Table III). In the CIK and Che-Sur groups, following 4-5 courses of CIK treatment, the levels of INF- $\gamma$ were significantly higher than those prior to the treatment (control) $(\mathrm{P}=0.002$ and 0.024 , respectively). By contrast, in the Che-Sur group the levels of IL-10 decreased following CIK treatment $(\mathrm{P}=0.019)$.

Effects of the percentage of $\mathrm{CD}^{+} \mathrm{CD} 56^{+} \mathrm{CIK}$ cells on the regulation of the immune function in patients with lung cancer. The number of $\mathrm{CD}^{+}{ }^{+} \mathrm{CD} 56^{+} \mathrm{CIK}$ cells that each patient received was different. Thus, to analyze whether this was a factor that influenced the different immune response observed across the patients, the differences in the number of $\mathrm{CD}^{+} \mathrm{CD}^{+}, \mathrm{CD}^{+}$, $\mathrm{NK}$ and NKT cells that were present in the peripheral blood of the patients the day prior to the following course of CIK treatment were analyzed and compared across the three groups (Low-CIK, Mid-CIK and High-CIK group). Due to limitations in the number of samples, changes in the numbers of these cells were only analyzed following the first three courses of CIK treatment. The results revealed that the number of $\mathrm{CD}^{+}{ }^{+} \mathrm{CD} 4{ }^{+}$and $\mathrm{CD}^{+}$cells did not vary across the three groups following each course of treatment (Fig. 2). NK cells increased with the increase in the percentage of $\mathrm{CD}^{+}{ }^{+} \mathrm{CD}^{2} 6^{+}$cells following the first and third courses, although there was no significant increase following the second course (Fig. 2). NKT cells exhibited a tendency to increase with the increase in the percentage of $\mathrm{CD}^{+} \mathrm{CD}^{+} 6^{+}$cells following the second course of CIK treatment, although the increase was not significant. Following the third course of treatment, the number of NKT cells increased with the increase in the percentage of $\mathrm{CD}^{+}{ }^{+} \mathrm{CD} 56^{+}$cells (Fig. 2).

\section{Discussion}

The incidence and mortality rates of lung cancer are reported to be the highest ones among all the malignancies worldwide (1). Patients with cancer usually have a poor prognosis, despite being subjected to surgery, chemotherapy or radiotherapy (19). Chemotherapy or radiotherapy may be useful to a certain 
extent; however, due to the high toxicity and other associated factors, the implementation and benefit of these treatments are largely hampered $(20,21)$.

Besides surgery, chemotherapy and radiotherapy, adoptive immunotherapy is a promising novel approach for the treatment of solid tumors (5). According to previous studies, cancer patients exhibit certain dysfunctions in cellular immunity, including innate and adaptive immune responses (22). Due to the low immune function displayed by patients with lung cancer, effective immune response cannot be achieved, and this is one of the reasons why malignant tumors are incurable $(23,24)$. Autoimmune disorders in patients lung cancer are demonstrated by reduced levels of $\mathrm{CD}^{+}$and $\mathrm{CD} 3^{+} \mathrm{CD} 56^{+}$cells, and increased levels of $\mathrm{CD}^{+}$cells $(25,26)$. The response of the human immune system against tumors mainly depends on cellular immunity (27). $\mathrm{CD}^{+} \mathrm{T}$ cells are mature $\mathrm{T}$ cells, while $\mathrm{CD}^{+}{ }^{+} \mathrm{T}$ cells are considered to have a predefined role as $\mathrm{Th}$ cells (28). It has been demonstrated that cytotoxicity against tumors is dependent on an appropriate interaction between $\mathrm{CD}^{+}$and $\mathrm{CD}^{+} \mathrm{T}$ cells (29). However, the ratios of $\mathrm{T}$ lymphocyte subsets in peripheral blood are usually disordered in cancer patients $(30,31)$. The proportion of these cells in the human body must remain constant in order to maintain its optimal state of balance and participate in cellular immune surveillance (32). NK and NKT cells are effector cells, which are involved in the immune response against tumors during the early stages of tumor development (33). These cells do not require any specific antibodies or presensitized lymphocytes to exert their function, and may be rapidly activated to suppress and destroy a variety of tumor cells (34). In addition, NK and NKT cells are more lethal upon being activated by lymphokines (34).

It has been reported that CIK cells regulate and enhance cellular immune functions in patients with cancer $(35,36)$. Thus, the clinical translation of adoptive immunotherapy with CIK cells as a potential treatment for patients with solid tumors has recently gained attention, and is currently under investigation in various clinical trials $(19,37)$. At present, immunotherapy has become the fourth treatment strategy for malignant tumors $(38,39)$. The use of CIK cells as adoptive immunotherapy against tumors has been reported in several studies $(36,39)$. CIK cells are heterogeneous cell populations of T lymphocytes that express CD3 and CD56, as well as NK group 2 , member $\mathrm{D}$, the activating receptor of NK cells $(9,40)$. CIK cells possess MHC-unrestricted tumor-killing activity, but do not display cytotoxicity toward normal cells $(9,40)$. In addition, CIK cells are considered to be antitumor effector cells, which easily expand in vitro and exhibit stronger antitumor activity compared with other antitumor effector cells $(41,42)$. Furthermore, CIK cells are able to regulate cellular immune functions in patients with cancer $(35,36)$. The application of CIK cells as adoptive immunotherapy is important in the treatment of cancer, since several clinical studies have confirmed the safety of CIK therapy for patients $(12,13)$. Numerous clinical studies have been recently performed, whereby adjuvant infusions of CIK cells following surgical resection demonstrated a significant increase in survival time $(43,44)$. In addition, CIK infusions were also able to reduce the viral load of hepatitis B virus (45).

In previous studies, the serum levels of tumor markers were significantly reduced following CIK cell infusion, and the short-term curative effect and quality of life improved in patients treated with CIK cells $(41,46)$. In the present study, the average percentage of $\mathrm{CD}^{+} \mathrm{CD}^{+}, \mathrm{CD}^{+}$and $\mathrm{NKT}$ cells, as well as the levels of IFN- $\gamma$ following several treatment courses, were significantly higher than the values observed prior to CIK treatment in the CIK and Che-Sur groups. Shi et al (47) observed that the percentage of $\mathrm{CD}^{+}$and $\mathrm{CD} 4^{+}$cells, and the ratio of $\mathrm{CD}^{+} / \mathrm{CD}^{+}$cells were significantly higher following the first course of CIK therapy, compared with the values prior to treatment. However, in the present study, the percentages of $\mathrm{CD}^{+}$and $\mathrm{CD}^{+}{ }^{+} \mathrm{CD} 4^{+}$cells were observed to be significantly higher following several courses of CIK therapy, which may be due to the difference in the detection time point (1 month in the current study vs. 2 weeks in the study by Shi et al subsequent to each course). Jin et al (48) reported that only one treatment course of CIK was unable to improve the immune function in patients with lung cancer. Several researches have reported that $\mathrm{CD}^{+}, \mathrm{CD}^{+} \mathrm{CD}^{+}$and other immune cells peaked at 4 weeks following CIK treatment, while circulating CIK cells persisted for $\leq 2$ weeks following infusion (11). Those studies suggested that several courses of CIK treatment would be required to achieve a stable effect $(47,48)$. The present findings indicate that CIK cell therapy aids to improve the immune status of cancer patients following several courses. Therefore, to gain therapeutic efficacy, multiple courses of therapy should be administered to the patients. Noticeably, in the present study, no changes were observed in the Che-Rad group during any of the courses. Thus, the treatments administered to the patients prior to CIK cell therapy seemed to affect the outcome, since more courses were required to achieve effective antitumor immune responses in the Che-Rad group, compared with patients who had not been exposed to radiotherapy prior to CIK treatment. It is interesting to note that the number of $\mathrm{CD}^{+} \mathrm{CD}^{+}$cells in the Che-Rad group was already lower than that in the CIK and Che-Sur groups prior to CIK treatment, whereas the number of NKT cells was higher in the Che-Rad group prior to CIK treatment, compared with the Che-Sur group. The reason for this discrepancy is unclear; however it may be caused by the treatment administered prior to CIK treatment, since the various treatments administered to the patients have different affects on immune cells.

At present, there is controversy regarding the number of cells required to be infused in CIK cell therapy, since the antitumor activity of CIK cells is mainly associated with the $\mathrm{CD} 3^{+} \mathrm{CD} 56^{+}$ fraction, rather than the $\mathrm{CD}^{+}$fraction, which constitutes the highest percentage of CIK cells (6). A previous study suggested that the improvements in immune function exerted by CIK cells were affected by the number of CIK cells (48). In the present study, the percentage of $\mathrm{CD}^{+}{ }^{+} \mathrm{CD} 56^{+}$cells was $\sim 18.9 \%$. Patients were divided into three groups according to the percentage of $\mathrm{CD}^{+}{ }^{+} \mathrm{CD} 56^{+}$cells that received in each course. It was observed that the number of $\mathrm{CD}^{+} \mathrm{CD}^{+}$and $\mathrm{CD}^{+} \mathrm{T}$ lymphocytes did not change in any of the three groups following each course of CIK treatment. These demonstrated that the number of CIK cells did not affect lymphocyte-associated functions. By contrast, the number of NK and NKT cells increased with the increase in the percentage of $\mathrm{CD} 3^{+} \mathrm{CD} 56^{+}$cells. Several studies have observed a markedly increased ratio of $\mathrm{CD}^{+} \mathrm{CD}^{+} 6^{+}$and $\mathrm{NK}$ cells following CIK treatment, compared with the levels observed prior to CIK treatment. In the present study, the number of NK 
and NKT cells increased following CIK treatment. When the number of $\mathrm{CD}^{+} \mathrm{CD}^{2} 6^{+}$cells present in the CIK cells infused back into the patients increased, the number of NK and NKT cells increased in the peripheral blood of the patients, which enabled the patients to effectively kill tumor cells.

The present study was a hospital-based study, which was a limitation, since only a small number of patients were enrolled in each group. In addition, only changes in the number of immune cells were analyzed in different cases. Therefore, future studies are required to confirm the present results and to evaluate the functions of these cells, such as cytokine secretion and cytotoxic activity.

In conclusion, the present study demonstrated that CIK cells enhanced the immune status of patients with lung cancer, although several courses of CIK treatment were required to observe the aforementioned effect. Patients who had not received any treatment and those who had been subjected to chemotherapy and surgical resection prior to CIK treatment, but not those who had received chemotherapy and radiotherapy prior to CIK treatment, were the most benefited ones from the CIK treatment, since additional courses of CIK therapy were required to achieve effective antitumor immune responses in these patients. The increase in the number of $\mathrm{CD}^{+} \mathrm{CD}^{+} 6^{+}$cells among the infused CIK cells notably enhanced the number of NK and NKT cells available to effectively exert an antitumor effect. The present results provide experimental evidence for the clinicians to select CIK therapy as a treatment for patients with lung cancer.

\section{References}

1. Torre LA, Bray F, Siegel RL, Ferlay J, Lortet-Tieulent J and Jemal A: Global cancer statistics, 2012. CA Cancer J Clin 65 : 87-108, 2015

2. Ahn SH, Han MS, Yoon JH, Jeon SY, Kim CH, Yoo HJ and Lee JC: Treatment of stage I non-small cell lung cancer with CyberKnife, image-guided robotic stereotactic radiosurgery. Oncol Rep 21: 693-696, 2009.

3. Park S, Kim IR, Baek KK, Lee SJ, Chang WJ, Maeng CH, Hong JY, Choi MK, Kim YS, Sun JM, et al: Prospective analysis of quality of life in elderly patients treated with adjuvant chemotherapy for non-small-cell lung cancer. Ann Oncol 24: 1630-1639, 2013.

4. Rice SJ, Miller B, Wagman M, Jamorabo DS, Liu X and Belani CP: Clinical approaches to immunotherapy in non-smal cell lung cancer: Current and future perspectives. Curr Mol Pharmacol: Jul 16, 2015 (Epub ahead of print)

5. Sangiolo D, Martinuzzi E, Todorovic M, Vitaggio K, Vallario A, Jordaney N, Carnevale-Schianca F, Capaldi A, Geuna M, Casorzo L, et al: Alloreactivity and anti-tumor activity segregate within two distinct subsets of cytokine-induced killer (CIK) cells: Implications for their infusion across major HLA barriers. Int Immunol 20: 841-848, 2008.

6. Kuçi S, Rettinger E, Voss B, Weber G, Stais M, Kreyenberg H, Willasch A, Kuçi Z, Koscielniak E, Klöss S, et al: Efficient lysis of rhabdomyosarcoma cells by cytokine-induced killer cells: Implications for adoptive immunotherapy after allogeneic stem cell transplantation. Haematologica 95: 1579-1586, 2010.

7. Hontscha C, Borck Y, Zhou H, Messmer D and Schmidt-Wolf IG: Clinical trials on CIK cells: First report of the international registry on CIK cells (IRCC). J Cancer Res Clin Oncol 137: 305-310, 2011.

8. Schmidt-Wolf IG, Negrin RS, Kiem HP, Blume KG and Weissman IL: Use of a SCID mouse/human lymphoma model to evaluate cytokine-induced killer cells with potent antitumor cell activity. J Exp Med 174: 139-149, 1991.

9. Thanendrarajan S, Nowak M, Abken H and Schmidt-Wolf IG: Combining cytokine-induced killer cells with vaccination in cancer immunotherapy: More than one plus one? Leuk Res 35: $1136-1142,2011$
10. Schmidt-Wolf IG, Finke S, Trojaneck B, Denkena A, Lefterova P, Schwella N, Heuft HG, Prange G, Korte M, Takeya M, et al: Phase I clinical study applying autologous immunological effector cells transfected with the interleukin-2 gene in patients with metastatic renal cancer, colorectal cancer and lymphoma. Br J Cancer 81: 1009-1016, 1999.

11. Sangiolo D: Cytokine induced killer cells as promising immunotherapy for solid tumors. J Cancer 2: 363-368, 2011.

12. Zhu Y,Zhang H,Li Y, Bai J,Liu L, Liu Y, Qu Y and Qu X: Efficacy of postoperative adjuvant transfusion of cytokine-induced killer cells combined with chemotherapy in patients with colorectal cancer. Cancer Immunol Immunother 62: 1629-1635, 2013.

13. Huang ZM, Li W, Li S, Gao F, Zhou QM, Wu FM, He N, Pan CC, Xia JC, Wu PH and Zhao M: Cytokine-induced killer cells in combination with transcatheter arterial chemoembolization and radiofrequency ablation for hepatocellular carcinoma patients J Immunother 36: 287-293, 2013.

14. Jiang J, Wu C and Lu B: Cytokine-induced killer cells promote antitumor immunity. J Transl Med 11: 83, 2013.

15. Zhang J, Zhu L, Zhang Q, He X, Yin Y, Gu Y, Guo R, Lu K, Liu L, Liu P and Shu Y: Effects of cytokine-induced killer cell treatment in colorectal cancer patients: A retrospective study. Biomed Pharmacother 68: 715-720, 2014.

16. Wang XP, Xu M, Gao HF, Zhao JF and Xu KC: Intraperitoneal perfusion of cytokine-induced killer cells with local hyperthermia for advanced hepatocellular carcinoma. World J Gastroenterol 19: 2956-2962, 2013.

17. Sobin LH, Gospodarowicz MK and Wittekind $\mathrm{CH}$ (eds.): TNM Classification of Malignant Tumours. 7th edition. Wiley-Blackwell, Hoboken, NY, 2009.

18. Schmidt-Wolf GD, Negrin RS and Schmidt-Wolf IG: Activated $\mathrm{T}$ cells and cytokine-induced $\mathrm{CD}^{+} \mathrm{CD}^{-} 6^{+}$killer cells. Ann Hematol 74: 51-56, 1997.

19. Zhang J, Zhu L, Wei J, Liu L, Yin Y, Gu Y and Shu Y: The effects of cytokine-induced killer cells for the treatment of patients with solid tumors: A clinical retrospective study. J Cancer Res Clin Oncol 138: 1057-1062, 2012.

20. Baas P, Belderbos JS and Van den Heuvel M: Chemoradiation therapy in nonsmall cell lung cancer. Curr Opin Oncol 23: 140-149, 2011.

21. Hsu HS, Huang PI, Chang YL, Tzao C, Chen YW, Shih HC, Hung SC, Chen YC, Tseng LM and Chiou SH: Cucurbitacin I inhibits tumorigenic ability and enhances radiochemosensitivity in nonsmall cell lung cancer-derived CD133-positive cells. Cancer 117: 2970-2985, 2011.

22. Sun K, Wang L and Zhang Y: Dendritic cell as therapeutic vaccines against tumors and its role in therapy for hepatocellular carcinoma. Cell Mol Immunol 3: 197-203, 2006.

23. Méndez R, Ruiz-Cabello F, Rodríguez T, Del Campo A, Paschen A, Schadendorf D and Garrido F: Identification of different tumor escape mechanisms in several metastases from a melanoma patient undergoing immunotherapy. Cancer Immunol Immunother 56: 88-94, 2007.

24. Wongkajornsilp A, Somchitprasert T, Butraporn R, Wamanuttajinda V, Kasetsinsombat K, Huabprasert S, Maneechotesuwan K and Hongeng S: Human cytokine-induced killer cells specifically infiltrated and retarded the growth of the inoculated human cholangiocarcinoma cells in SCID mice. Cancer Invest 27: 140-148, 2009.

25. Lee WC, Wu TJ, Chou HS, Yu MC, Hsu PY, Hsu HY and Wang CC: The impact of $\mathrm{CD}^{+} \mathrm{CD}^{2} 5^{+} \mathrm{T}$ cells in the tumor microenvironment of hepatocellular carcinoma. Surgery 151: 213-222, 2012.

26. Chen KJ, Zhou L, Xie HY, Ahmed TE, Feng XW and Zheng SS: Intratumoral regulatory $T$ cells alone or in combination with cytotoxic $\mathrm{T}$ cells predict prognosis of hepatocellular carcinoma after resection. Med Oncol 29: 1817-1826, 2012.

27. Perdicchio M, Cornelissen LA, Streng-Ouwehand I, Engels S, Verstege MI, Boon L, Geerts D, van Kooyk Y and Unger WW: Tumor sialylation impedes $\mathrm{T}$ cell mediated anti-tumor responses while promoting tumor associated-regulatory $\mathrm{T}$ cells. Oncotarget. Jan 5, 2016 (Epub ahead of print).

28. Attallah AM, Tabll AA, El-Sadany M, Ibrahim TA and El-Dosoky I: Dysregulation of blood lymphocyte subsets and natural killer cells in schistosomal liver cirrhosis and hepatocellular carcinoma. Clin Exp Med 3: 181-185.

29. Motz GT and Coukos G: Deciphering and reversing tumor immune suppression immunity. Immunity 39: 61-73, 2013.

30. Kiessling R, Wasserman K, Horiguchi S, et al: Tumor-induced immune dysfunction. Cancer Immunol Immunother 48: 353-362, 1999. 
31. Rayman P, Uzzo RG, Kolenko V, Bloom T, Cathcart MK, Molto L, Novick AC, Bukowski RM, Hamilton T and Finke JH: Tumor-induced dysfunction in interleukin-2 production and interleukin-2 receptor signaling: A mechanism of immune escape. Cancer J Sci Am 6 (Suppl 1): S81-S87, 2000.

32. Shepherd FA, Douillard JY and Blumenschein GR Jr: Immunotherapy for non-small cell lung cancer: Novel approaches to improve patient outcome. J Thorac Oncol 6: 1763-1773, 2011.

33. Subleski JJ, Wiltrout RH and Weiss JM: Application of tissue-specific NK and NKT cell activity for tumor immunotherapy. J Autoimmun 33: 275-281, 2009.

34. Kuss I, Hathaway B, Ferris RL, Gooding W and Whiteside TL: Decreased absolute counts of $\mathrm{T}$ lymphocyte subsets and their relation to disease in squamous cell carcinoma of the head and neck. Clin Cancer Res 10: 3755-3762, 2004.

35. Schmidt-Wolf IG, Lefterova P, Mehta BA, Fernandez LP, Huhn D, Blume KG, Weissman IL and Negrin RS: Phenotypic characterization and identification of effector cells involved in tumor cell recognition of cytokine-induced killer cells. Exp Hematol 21: 1673-1679, 1993.

36. Joshi PS, Liu JQ, Wang Y, Chang X, Richards J, Assarsson E, Shi FD, Ljunggren HG and Bai XF: Cytokine-induced killer $\mathrm{T}$ cells kill immature dendritic cells by TCR-independent and perforin-dependent mechanisms. J Leukoc Biol 80: 1345-1353, 2006.

37. Chen Y, Lin WS, Zhu WF, Lin J, Zhou ZF, Huang CZ, Chen G, Shi Y, Guo ZQ, and Ye YB: Tumor MICA status predicts the efficacy of immunotherapy with cytokine-induced killer cells for patients with gastric cancer. Immunol Res 64: 251-259, 2016.

38. Blattman JN and Greenberg PD: Cancer immunotherapy: A treatment for the masses. Science 305: 200-205, 2004.

39. Liu L, Zhang W, Qi X, Li H, Yu J, Wei S, Hao X and Ren X: Randomized study of autologous cytokine-induced killer cell immunotherapy in metastatic renal carcinoma. Clin Cancer Res 18: 1751-1759, 2012.

40. Verneris MR, Karimi M, Baker J, Jayaswal A and Negrin RS Role of NKG2D signaling in the cytotoxicity of activated and expanded CD8 ${ }^{+}$T cells. Blood 103: 3065-3072, 2004.
41. Schwaab T, Schwarzer A, Wolf B, Crocenzi TS, Seigne JD, Crosby NA, Cole BF, Fisher JL, Uhlenhake JC, Mellinger D, et al: Clinical and immunologic effects of intranodal autologous tumor lysate-dendritic cell vaccine with Aldesleukin (Interleukin 2) and IFN-\{alpha\}2a therapy in metastatic renal cell carcinoma patients. Clin Cancer Res 15: 4986-4992, 2009.

42. Li R, Wang C, Liu L, Du C, Cao S, Yu J, Wang SE, Hao X, Ren $\mathrm{X}$ and Li H: Autologous cytokine-induced killer cell immunotherapy in lung cancer: A phase II clinical study. Cancer Immunol Immunother 61: 2125-2133, 2012.

43. Jiang JT, Shen YP, Wu CP, Zhu YB, Wei WX, Chen LJ, Zheng X, Sun J, Lu BF and Zhang XG: Increasing the frequency of CIK cells adoptive immunotherapy may decrease risk of death in gastric cancer patients. World J Gastroenterol 16: 6155-6162, 2010.

44. Niu Q, Wang W, Li Y, Qin S, Wang Y, Wan G, Guan J and Zhu W: Cord blood-derived cytokine-induced killer cells biotherapy combined with second-line chemotherapy in the treatment of advanced solid malignancies. Int Immunopharmacol 11: 449-456, 2011.

45. Shi M, Zhang B, Tang ZR, Lei ZY, Wang HF, Feng YY, Fan ZP Xu DP and Wang FS: Autologous cytokine-induced killer cell therapy in clinical trial phase I is safe in patients with primary hepatocellular carcinoma. World J Gastroenterol 10: 1146-1151, 2004.

46. Jiang J, Xu N, Wu C, Deng H, Lu M, Li M, Xu B, Wu J, Wang R, $\mathrm{Xu} \mathrm{J}$ and Nilsson-Ehle P: Treatment of advanced gastric cancer by chemotherapy combined with autologous cytokine-induced killer cells. Anticancer Res 26: 2237-2242, 2006.

47. Shi L, Zhou Q, Wu J, Ji M, Li G, Jiang J and Wu C: Efficacy of adjuvant immunotherapy with cytokine-induced killer cells in patients with locally advanced gastric cancer. Cancer Immunol Immunother 61: 2251-2259, 2012.

48. Jin CG, Chen XQ, Li J, Wu ZP, Liu X and Wang XC: Moderating effects and maintenance of lung cancer cellular immune functions by CIK cell therapy. Asian Pac J Cancer Prev 14: 3587-3592, 2013 . 